\title{
Grassroots information service station performance appraisal system based on cloud computing environment
}

\author{
Chun-Mei Deng ${ }^{1, a}$, Mao-Fen Li $i^{1, b}$, Wei Luo ${ }^{2, c}$, Zheng-Hui Xie ${ }^{1, d}$
}

${ }^{1}$ Institute of science and technology information, Chinese academy of tropical agricultural sciences,

\author{
Danzhou 571737, China
}

${ }^{2}$ Rubber institute, Chinese academy of tropical agricultural sciences, Danzhou 571737, China

aemail:dcmf2930@163.com, ${ }^{b}$ email:1034913270@qq.com, ${ }^{c} e m a i l: 615744175 @ q q . c o m,{ }^{d}$ email:1912

2434@qq.com

Keywords: Cloud Computing; Performance Appraisal; Information Service

\begin{abstract}
In order to promote rural informatization, it is necessary to measure the information service management work scientifically. Effective performance evaluation and scientific incentive system for evaluating the work of grassroots service stations, is not only the basis of the grassroots service station management, but also is the key to grassroots service station sustainable development. There are kinds of fairly detailed assessment system for the service stations all over China, but the performance evaluation is time-consuming and inefficient. According to the actual situation of China's primary service stations, a performance appraisal system for evaluating the grassroots information service station performance based on cloud computing environment is designed and implemented. In this paper, we apply our system to Hainan Agricultural Science 110 service stations base on cloud computing environment. And using the qualitative and quantitative research methods to design the combination of system.
\end{abstract}

\section{Introduction}

The research of performance evaluation began of the last century, which Robert Owens first bring performance appraisal in Scotland. Campen (1993) argue that performance including associated with organizational goals, and can be carried out in accordance with the individual's ability (i.e., the degree of contribution) measurement [1]. In China, most studies tend to Human Resource Management and universities. Research on the performance evaluation of grassroots information service station is little. Grassroots information service stations is a rural information work carried out fundamental guarantee [2]. With the rapid development of information technology and grassroots information service station , the traditional performance appraisal management is unable to provide an effective evaluation. First, the traditional performance appraisal with manual processing is time-consuming, affecting the timeliness grassroots information service station and advancement. Secondly, the current assessment process is enclosed for public and the station staff, there will inevitably be inequities. Finally, the traditional appraisal way is unable to store the historical information for statistical analysis, so it cannot result a comprehensive evaluation for grassroots information service station in the long term. . Above all, establishing a sound performance appraisal system based on the computer science and technology to improve performance management service station is necessary. Since the system is oriented to the whole grassroots information service sites in China, there will appears a large amount of data in this system. Cloud computing is a virtualization technology, and it is web-based carrier to provide infrastructure services, platform services and software services, and is capable of the integration of massively scalable computing, storage, data and applications of distributed computing resources to work super-computing model[3-4].So taking advantage of cloud computing service to sites performance appraisal operation, massive data mining and analysis, so that the evaluation results just, by award punitive inferior mechanisms to promote service sites lasting operation, encourage service station information officer service attitude. 


\section{Construction of Performance Appraisal Index System}

\section{The Principles of Performance Appraisal.}

The most basic principle of performance evaluation is open and fair. Firstly, the evaluation criteria such as evaluation categories, projects, specific gravity and so on must be very clear. Secondly, the evaluation criteria should be based on kinds of services of grass-roots information service station, and the evaluation rules must depend on the actual situation to develop. Since the evaluation is a continuous management process, performance evaluation should be regular and institutionalized.

\section{Content of Performance Appraisal.}

Content is scientific and reasonable performance evaluation directly affecting the quality of grassroots information service station job performance. And therefore, the content of evaluation is very important. Daily job of grassroots stations is to provide farmers with a variety of agriculture-related information services, to carry out various forms of technical training, reporting kinds of policies from the higher authorities to farmers, rural training, i.e. Therefore, evaluation mainly comprise the basic services for grassroots information service station, technical advice and training and other related business.

\section{Weight Allocation}

Because the time required reaching a different outcome of the work, the focus of evaluation is different. Conditions of grassroots information service station, service types and efforts degree are not the same, and these differences is very important to determine the evaluation indicators corresponding weight. Accurate and reasonable weight, managers can make a more objective evaluation of job performance to service stations. The content of the performance index system is the core of performance evaluation. Table 1 shows the indicators and weight distribution for grassroots information service station performance evaluation, according to the actual situation. The year-end ranking is based on the final scoring accumulate.

Table 1 Performance indicators and weight distribution table for grassroots information service station

\begin{tabular}{|c|c|c|c|c|}
\hline No. & Level indicators & Secondary indicators & Unit & Weights \\
\hline 1 & \multirow{3}{*}{ Basic Service } & Personnel allocation & $\%$ & 20 \\
\hline 2 & & Grassroots Post & $\%$ & 15 \\
\hline 3 & & $\begin{array}{c}\text { Equipment of information } \\
\text { technology }\end{array}$ & $\%$ & 10 \\
\hline 4 & \multirow{3}{*}{ Technical advice, training } & Hotline & $\%$ & 10 \\
\hline 5 & & Live consultation & $\%$ & 10 \\
\hline 6 & & Technical Training & $\%$ & 10 \\
\hline 7 & \multirow{2}{*}{$\begin{array}{l}\text { Agricultural materials } \\
\text { sales }\end{array}$} & Area of storing and sales region & $\%$ & 5 \\
\hline 8 & & Sales of integrity situation & $\%$ & 5 \\
\hline 9 & \multirow{2}{*}{$\begin{array}{l}\text { Sales of agricultural } \\
\text { products }\end{array}$} & Area of agricultural base & $\%$ & 5 \\
\hline 10 & & Sales of integrity situation & $\%$ & 5 \\
\hline 11 & Other activities & & $\%$ & 5 \\
\hline
\end{tabular}




\section{Evaluation Method}

The Performance evaluation has many methods. First, we must understand the content characteristics of the various evaluation methods, and then according to the requirements and purposes to be achieved by choosing the best evaluation method. With special attention to differences in evaluation methods and the applicability of different evaluation methods applied to performance appraisal. The performance appraisal system of grassroots information service stations adopted objective methods, it based on information generally can be quantitative, rigid indicators. The method based on objective criteria for grassroots service station business work for evaluation, including the critical incident technique, grade identification method. In the current study, the performance evaluation is depending on the type of business service station at the grass-roots level. In accordance with the standards of evaluation give a score or quantify the extent of the judgment. Afterwards, use the method of accumulated of aggregation for the service station in all aspects scores. The later, we will obtain results of basic information service station a comprehensive evaluation.

\section{Performance appraisal system function design based on cloud computing environment}

Cloud computing service models can be divided into three categories: IaaS (Infrastructure as a Service) 、 PaaS (Platform as a Service)and SaaA (Software as a Service).Iaas is hardware equipment and other basic resources as a service package available to users. PaaS provides users of the application runtime environment, such as Microsoft cloud computing operating system Microsoft WindowsAzure.SaaA only provide some of the special-purpose service supply with calls [5]. In the cloud computing environment, the performance evaluation system services mainly accept from multiple service sites in the evaluation of instruction. Cloud computing services will review the data stored in the cloud, where the unified platform provided by the subsystem data security and protection. It will reduce the user data is stored in the computer on the risks. Figure 1 is shown function design of cloud environment based performance appraisal system. The system uses provincial centers, city and county centers, service station three-tier system.

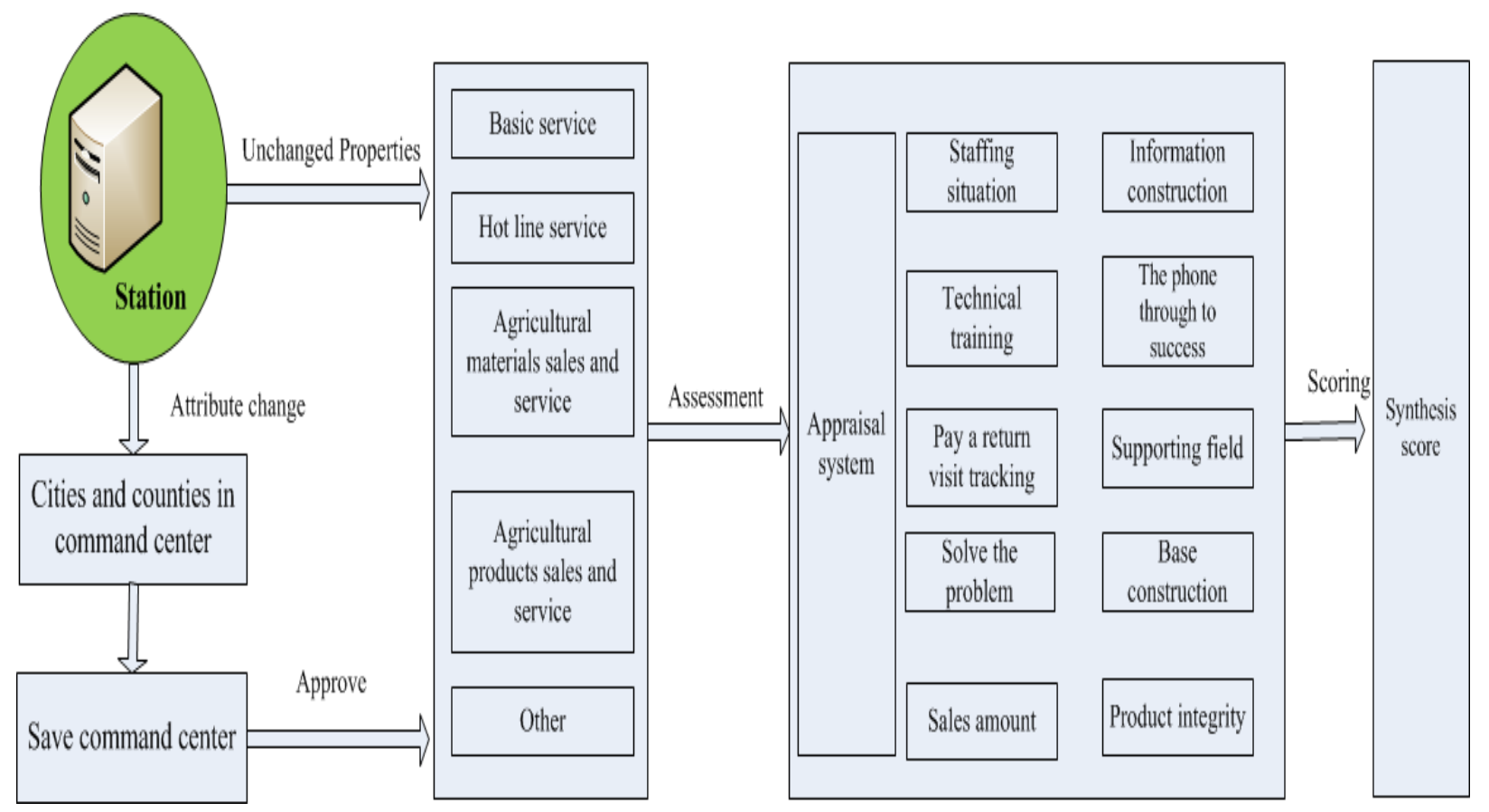

Figure 2 Function design of cloud environment based performance appraisal system 


\section{Implement cloud computing environment performance evaluation system}

Hainan Agricultural Science 110 service stations service station depend on the type of service business development are also different. It mainly divides into five large businesses: basic service, technical advice, training, agricultural sales, sales of agricultural products and other businesses. The performance appraisal system according to the five kinds of business for automatic accumulation scores, end up with getting a score of statistics. Service station actual property can be any number of combinations of basic business model and the other four kinds of business types, the basic business model as the core.

A. The basic business model: Performance appraisal system will be equipped with information based on the service site administrator entry site personnel, the number of daily publishing and information-based construction information, and so the conditions for automatic scoring.

B. Technical advice and training type: The hotline received, the on-site consultation to solve the problem, the return visit tracking and so on.

C. Agricultural sales service: According to the service station area of agricultural store sales, sales and service integrity to evaluate the situation.

D. Agricultural Marketing Service: Assessment indicators contain agricultural base construction area, the site sales service integrity, etc.

E. Other activities: including micro-credit - loan amount and institutions, the amount of subsidies mainly include the microfinance - loan amount and structure, the amount of subsidies case.

Managerial personnel at the provincial level can be according conditions to find business performance data of the cities and counties in the province service site. The performance score data be unification under the grass-roots service site integrated management system. The data using a cache Redis to save. Server data with local cache is synchronized. Not only to ensure the speed of data storage, but also to provide security for the data.

\begin{tabular}{|c|c|c|c|c|c|c|c|c|c|c|}
\hline 分我的主页 & \multicolumn{10}{|l|}{ 对各个站点的评 $x$} \\
\hline \multirow{13}{*}{ 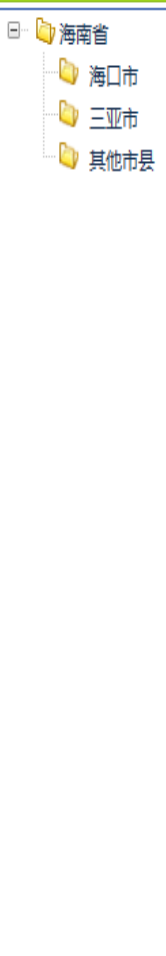 } & & \multicolumn{9}{|c|}{ 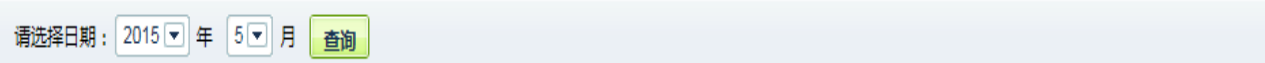 } \\
\hline & 基本业务 & 农资业务 & 农产品业务 & 咨洵业务 & & & & & & \\
\hline & 操作 & 详細 & 所属站点 & 基本业务 & 农资业务 & 农产品业务 & 技术咨询业务 & 技术培训业务 & 人工打分 & 总分 \\
\hline & 1 & $\hat{0}$ & 长流服务站 & 4 & & & 0 & & 23 & 27 \\
\hline & 2 & हैं & hainan & 4 & & & 0 & 0 & 24 & 28 \\
\hline & 2 & हैं & 哈甞瓜服务站 & 2 & 0 & 0 & & & 28 & 30 \\
\hline & 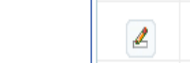 & 80 & 信息所 & 4 & & & 0 & 0 & 22 & 26 \\
\hline & 1 & $\delta$ & xinxisuo2 & 9 & 5 & 2 & 15 & 16 & 29 & 76 \\
\hline & 2 & 80 & danzhou & 4 & & & & & 0 & 4 \\
\hline & 2 & $\hat{\theta}$ & 鮘州宝岛 & 4 & 0 & 0 & 0 & 0 & 0 & 4 \\
\hline & 4 & $\hat{\delta}$ & 崖棫 & 4 & & & & & 0 & 4 \\
\hline & 4 & $\hat{0}$ & 隐州大成110腵务站 & 10 & 2 & 2 & 0 & 0 & 0 & 14 \\
\hline & 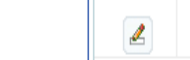 & $\hat{6}$ & 海南当指挂中心汻侙 & 2 & & & 0 & 0 & 0 & 2 \\
\hline
\end{tabular}

Figure 3 Score interface of cloud computing based basic services site performance evaluation system 


\section{Advantages of cloud computing based grassroots information service site performance appraisal system}

In the cloud computing environment, large-capacity server cluster computing capability not only improves the performance appraisal system. Reading and writing data, collection and processing capacity has been greatly improved. Storage costs is low also makes the storage resource pool to rapid deployment. The management department monitoring information service station at the grass-roots level. Information retrieval is not restricted by hardware conditions. Not only improve the work efficiency and lowering the grass-roots service station construction costs, but also makes storage resource pools to quickly deploy. Upper management in monitoring grassroots information service station, information retrieval from a hardware limit conditions, improve work efficiency and reduce the cost of basic services station construction. Each primary service sites can according to scores improvements the service mechanism service stations.

\section{Conclusion}

Performance evaluation system is based on a sub-base layer information service site cloud computing model integrated management system under the grass-roots information service site. The integrated management system aims to improve grassroots information service site resource sharing, information services capability grassroots information service site. System can be to manage the rural information service and information staff the site of informatization work. That achieves the innovation mode to the farmers as the center of the rural information service.

\section{Acknowledgement}

This research was sponsored by National 12th five-year technology based plan topic from ministry of science and technology of the people's republic of China named the design and application of Cloud-based service management system for rural sci-tech information service station (2013BAD15B01-3).

\section{References}

[1] Campbell.J.P..Macloy.R.A. A theory of performance. Personal Selection in Organizations. San Francisco.Jossey-Bass.1993.P35-70

[2] Dao-Liang Li. The rural information service station needs innovative operation mode. China, 2010.

[3] Li Qiao add Zheng Xiao. Cloud computing research status review. Journal of computer science, Vol, 38(2013), p.32-37.

[4] Fang, literature, Mr. Wu, pan etc. Cloud computing: concepts, technology and application research review $[\mathrm{J}]$. Journal of Nanjing information engineering university (natural science edition), 2012, 4 (4): 351-361.

[5] Zhang Li-Guo, WU Chao, SHI Guang-Yi, Construction of Agricultural Information Service System Based on Cloud - Computing and WebGis, Hubei Agricultural Sciences,Vol.52 No.5Mar.2013. 